
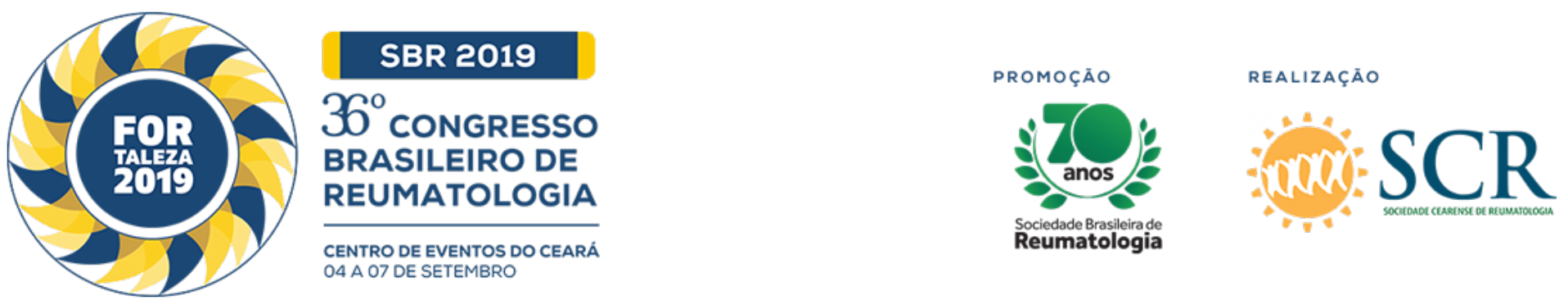

\title{
LIMB-GIRDLE MUSCULAR DYSTROPHY AS A DIFFERENTIAL DIAGNOSIS IN PATIENT PRESENTING WITH WEAKNESS AND ELEVATION OF MUSCULAR ENZYMES OF CHRONIC EVOLUTION: A CASE REPORT
}

Flávio Ribeiro Pereira (UFRJ- Campus Macaé, Macaé, RJ, Brasil), Jannine Farias Bellini Leite (UFRJCampus Macaé, Macaé, RJ, Brasil), Isabella Matias Ribeiro (UFRJ-Campus Macaé, Macaé, RJ, Brasil), Fernanda Marvila Fagundes Lamarca (UFRJ- Campus Macaé, Macaé, RJ, Brasil), Natália Miranda Gava (UFRJ- Campus Macaé, Macaé, RJ, Brasil), Ingrid Carvalho Andrade (UFRJ-Campus Macaé, Macaé, RJ, Brasil), Nádia Christina Maia Moreira (UFRJ- Campus Macaé, Macaé, RJ, Brasil), Paula Amanda Starling Alves (UFRJ- Campus Macaé, Macaé, RJ, Brasil)

\section{BACKGROUND}

The limb-girdle muscular dystrophy represents a clinically and genetically heterogenic group of muscular degenerative diseases of dominant and recessive autossomic inheritance. The following case report presents the diagnostic investigation on a patient with the characteristic clinical condition, plus a history of parental consanguinity.

\section{CASE REPORT}

T.V.B., 27 years-old, Caucasian, single, complaining of proximal muscle weakness of lower limbs and pelvic girdle, unable to specify its evolution period precisely. Denies previous comorbidities and use of any medication or illicit drugs. On the exam, presents with grade 3 strength on lower limbs, preserved strength on upper limbs and bilateral hypertrophy of the calves. Laboratory exams demonstrate negative viral serologies, hemogram and renal function tests without alterations (including antinuclear antibody test and anti- Jo1), AST 97, ALT 111 and CPK 3770, the latter having remained high in subsequent exams. The investigation for neoplasia was negative and there were no clinical or radiological evidences of interstitial pulmonary disease. For diagnostic elucidation, a magnetic resonance imaging test was requested, revealing atrophy with bilateral and symmetrical liposubstitution in all gluteal and abductor thigh muscles, suggesting chronic myopathy. The patient underwent electromyography, which demonstrated myopathy with a predominance on the proximal pelvic girdle. A muscle biopsy demonstrated muscular tissue with nonspecific myopathic alterations and an increase of internalized nuclei; muscular dystrophy was not ruled out. After extensive genetic analysis, the pathogenic mutation in homozygosity of the Fukutin 21 gene was identified by molecular test, indicating the diagnosis of limb-girdle muscular dystrophy of type $2 \mathrm{l}$, until now, an untreatable genetic disease. It was established as conduct guidance regarding the practice of muscle strengthening exercise and genetic counseling.

\section{CONCLUSION}

The diagnosis of limb-girdle dystrophy is not common, especially considering the range of possibilities for differential diagnosis in patients with muscle weakness and altered mscle enzymes. However, adding the history of consanguinity of the patient's parents to her clinical and laboratory presentation, it was possible to direct the investigation and reach the diagnostic conclusion. 